\title{
BAHASA INDONESIA PADA RUBRIK ESAI MEDIA ONLINE MOJOK DAN PENGGUNAANNYA DALAM PEMBELAJARAN MENULIS ARTIKEL DI SEKOLAH MENENGAH ATAS
}

\author{
Alfi Nur Jannah, Budhi Setiawan, Kundharu Saddhono \\ Universitas Sebelas Maret \\ Email : alfijannah12@gmail.com
}

\begin{abstract}
Abstrak: Penelitian ini bertujuan untuk mendeskripsikan: (1) kesatuan struktur esai; (2) pengorganisasian bahasa terkait kohesi dan koherensi; (3) efektivitas kalimat; (4) ketepatan penggunaan diksi; (5) ketepatan penggunaan ejaan (6) relevansi penggunaan bahasa Indonesia pada media online Mojok dan terhadap pembelajaran menulis artikel di sekolah menengah atas. Metode yang digunakan kualitatif deskriptif. Sumber data yang digunakan berupa dokumen dan informan. Teknik pengambilan sampel menggunakan purposive sampling. Teknik pengumpulan data menggunakan teknik analisis dokumen dan wawancara. Validitas data dilakukan dengan triangulasi teori dan triangulasi sumber. Analisis data menggunakan analisis isi. Hasil penelitian dapat diuraikan sebagai berikut. (1) Struktur esai baik judul, pendahuluan, isi dan penutup telah memiliki kesatuan yang baik; (2) Pengorganisasian bahasa terkait kohesi dan koherensi; (3) Efektivitas kalimat; (4) Ketepatan penggunaan diksi; (5) Ketepatan penggunaan ejaan; (6) Penggunaan bahasa Indonesia pada rubrik Esai media online Mojok yang relevan dengan pembelajaran menulis artikel di sekolah menengah atas.
\end{abstract}

Kata kunci : penggunaan bahasa Indonesia, esai, pembelajaran menulis artikel

\section{INDONESIAN LANGUAGE ON ESSAY RUBRIC OF MOJOK ONLINE MEDIA AND ITS USE IN LEARNING WRITING ARTICLES IN SENIOR HIGH SCHOOL}

\begin{abstract}
This study aims are: (1) to describe the relation of the title to the content; (2) to describe the organization of languages related to cohesion and coherence; (3) to describe sentence effectiveness; (4) to describe accuracy of diction usage; (5) to describe the correct use of spelling and punctuation; (6) to describe the relevance of the use of Indonesian language in Essay rubric of Mojok online media to learning writing articles in Senior High School. The method used is descriptive qualitative, Data sources used in the form of documents and informants. The sampling technique uses purposive sampling. Data collection technique using document analysis and interview techniques. Data validity is done by theory triangulation and source triangulation. Data analysis uses content analysis. The results of the study can be described as follows: (1) The structure of the essay in the title, introduction, content and closing has a good unity; (2) Organizing language related to cohesion and coherence; (3) The effectiveness of sentences; (4) The correct use of diction; (5) Accuracy in using spelling punctuation; (6) The use of Indonesia language in the Essay Rubric of Mojok online media is relevant to write articles in senior high school.
\end{abstract}

Keywords: the use of Indonesia language, essays, learning to write articles

\section{PENDAHULUAN}

Bahasa merupakan salah satu perangkat komunikasi yang mempunyai peran penting dalam kehidupan manusia. Manusia menggunakan bahasa untuk menyampaikan pesan dan mengemukakan gagasannya baik secara lisan maupun tertulis. Kemampuan atau keterampilan berbahasa mempengaruhi kecerdasan berpikir seseorang termasuk kemampuan untuk menyampaikan gagasannya. keterampilan berbahasa mencakup: keterampilan menyimak, berbicara, menulis, dan membaca (Saddhono dan Slamet, 2012:3). Salah satu keterampilan berbahasa yang dapat menjadi sarana 
berkomunikasi sekaligus menyampaikan gagasan seseorang kepada masyarakat luas adalah dengan menulis. Terdapat beragam bentuk karya lisan dan tulisan yang dapat diciptakan manusia untuk menjadi sarana penyampaian gagasannya baik dalam wujud karya fiksi maupun non fiksi. Salah satu bentuk karya tulisan non fiksi adalah karya ilmiah populer. Karya ilmiah populer merupakan salah satu bentuk tulisan ilmiah yang menggunakan bahasa secara sederhana sehingga mudah dipahami dan menarik untuk dibaca (Dalman, 2015:15). Karya ilmiah ini disebut populer karena dapat diterima oleh seluruh lapisan masyarakat. Contoh karya ilmiah populer yang umum dijumpai masyarakat melalui media massa adalah artikel esai.

Esai adalah tulisan non fiksi yang terdiri atas beberapa paragraf yang membahas satu topik dimana antar paragraf saling berkaitan untuk membentuk kesatuan gagasan. Esai merupakan tulisan yang terdiri dari beberapa paragraf yang membentuk satu kesatuan gagasan (Helaluddin, 2017:17). Berbeda dengan karya fiksi, sebuah esai ditulis dengan menggunakan metode khusus untuk mendapatkan data-data mengenai topik tertentu untuk kemudian dipaparkan oleh penulis dalam suatu perspektif. Esai merupakan jenis tulisan yang memungkinkan penggabungan faktafakta dengan imajinasi, atau penggabungan pengetahuan dan perasaan (Numertayasa, Sutarna, \& Rasna, 2013:4). Artikel esai dapat ditulis berdasarkan pengalaman pribadi penulis. Hal ini membuat tulisan tersebut memiliki otoritas. Esai merupakan bentuk tulisan yang membahas suatu masalah mulai dari menyajikan masalah, mengemukakan imajinasi, dan pendapat pribadi penulis yang didukung oleh fakta dan teori (Rahayu, 2007:143). Gagasan di dalam sebuah esai menawarkan sebuah perspektif baru kepada pembaca.

Struktur esai terdiri atas tiga bagian yaitu bagian pendahuluan, bagian penjelas, dan bagian penyimpul (Budiyono, 2012:15). Bagian paragraf pembuka adalah bagian awal esai yang berisi gambaran umum mengenai suatu peristiwa. Bagian ini biasanya terdiri dari satu paragraf. Kemudian ada bagian kedua yang berisi paragraf-paragraf pengembang yang berisi pemaparan argumen berdasarkan data yang didapat oleh penulis. Lalu bagian terakhir, yaitu penutup adalah simpulan dari argumen-argumen yang telah dijabarkan oleh penulis. Komponen yang mengacu pada keterampilan menulis meliputi (1) isi, yang meliputi relevansi, tesis yang dikembangkan, keeksplisitan analisis, dan ketepatan simpulan; (2) organisasi isi, yang meliputi, keutuhan, perpautan, pengembangan gagasan atau pikiran pokok paragraf, dan keseluruhan karangan, (3) gramatika atau tata bahasa, yang meliputi ketepatan penggunaan kata berkenaan dengan gagasan yang dikemukakan, kesesuaian penggunaan kata dengan konteks, dan kebakuan kata; (5) ejaan, yang meliputi penulisan huruf, kata, dan tanda baca (Saddhono dan Slamet, 2012:112).

Esai banyak terdapat di media massa, salah satunya media online berbahasa Indonesia bernama Mojok yang berbasis website dengan alamat www.Mojok.co. Mojok berdiri sejak 28 Agustus 2014 di Yogyakarta sebagai media alternatif berisi konten-konten yang memuat beragam artikel opini dari para redaktur dan kontributor luar. Media ini mempunyai rubrik utama yang bernama Esai. Rubrik Esai memuat esai-esai mengenai beragam isu segar yang tidak banyak diperbincangkan khalayak. Struktur kepenulisan di rubrik Esai sangat berbeda dengan artikel lain di mana setiap artikel mampu memberikan informasi baru mengenai satu topik tertentu dengan bahasa yang menarik sekaligus memberikan perspektif baru yang tegas. Keterampilan menulis artikel merupakan salah satu materi yang terdapat dalam pembelajaran bahasa Indonesia kelas XII SMA semester 2. Artikel adalah tulisan yang bersifat objektif dan bertujuan untuk menyampaikan pernyataan pribadi 
berdasarkan keyakinan dan sikap yang dimiliki penulis (Hasim dan Jamal, 2012: 16).

Berbagai aspek struktur penulisan esai dapat menjadi salah satu sarana untuk mengasah keterampilan menulis dan menyampaikan gagasan dalam bentuk artikel. Penelitian-penelitian mengenai struktur kepenulisan esai dapat memberikan solusi kepada guru dalam memilih bahan ajar materi menulis artikel di sekolah. Berdasarkan paparan-paparan di atas, penulis memilih rubrik Esai Mojok sebagai objek penelitian karena rubrik ini memuat artikel-artikel esai yang membahas isu terkini dengan memberikan suatu sudut pandang baru yang berbeda dari pembahasan masalah yang sama di media lain. Selain itu, setiap artikel di Mojok mempunyai struktur dan gaya bahasa yang unik dan khas yang bukan hanya menarik namun juga mengesankan dengan tetap memperhatikan kaidah kebahasaan yang baik dan benar. Beberapa alasan itu cukup kuat untuk membuat artikel Esai di media online Mojok menjadi sumber pembelajaran menulis artikel di SMA. Penulis mengharapkan penelitian ini dapat memberikan manfaat kepada pembaca.

\section{METODE PENELITIAN}

Penelitian terhadap penggunaan bahasa Indonesia pada rubrik Esai media online Mojok merupakan penelitian kualitatif deskriptif dengan menggunakan metode analisis isi (content analyis). Data dalam penelitian ini yaitu hasil catatan kutipan-kutipan penggunaan lima aspek bahasa Indonesia pada rubrik Esai media online Mojok sesuai dengan rumusan masalah penelitian ini. sumber data pa penelitian ini adalah sepuluh esai pada rubrik Esai media online Mojok edisi bulan Agustus 2019 dan informan yang mencakup penulis esai, guru bahasa Indonesia, dan siswa kelas XII. Teknik pengumpulan data yang digunakan yaitu analisis dokumen dan wawancara mendalam. Validasi data yang digunakan adalah triangulasi sumber data.

\section{HASIL DAN PEMBAHASAN \\ Penggunaan Bahasa Indonesia pada Rubrik Esai Media Online Mojok}

Data berupa dokumen dalam penelitian ini bersumber dari rubrik Esai media online Mojok edisi bulan Agustus 2019. Sepuluh artikel esai rubrik Esai dianalisis dalam penelitian ini untuk menjawab rumusan masalah yang terkait dengan penggunaan bahasa Indonesia. Terdapat lima aspek penggunaan bahasa Indonesia yang dianalisis yaitu aspek keterkaitan judul dengan isi, kohesi dan koherensi, efektivitas kalimat, penggunaan diksi, dan penggunaan tanda baca.

\section{Kesatuan Struktur Esai}

Judul merupakan pengantar karangan yang didapatkan setelah penentuan tema dan topik karangan. Pembaca dapat mengetahui gambaran isi atau permasalahan di dalam tulisan sehingga sebuah artikel harus memiliki judul yang relevan dengan isi tulisan (Saddhono dan Slamet 2012:). Pada penelitian ini, kesatuan struktur esai ditunjukkan dengan argumen-argumen yang dibangun penulis di setiap bagian esai mulai dari judul, pendahuluan, isi, hingga penutup membahas satu tema yang sama tanpa ada bagian yang menyimpang.

Pada esai edisi 1 tanggal 1 Agustus 2019 yang berjudul Kesel Ditipu Ria Ricis tapi Kok Tahan Dikerjain Politisi digambarkan dua situasi yang berbeda ketika satu peristiwa terjadi. Peristiwa tersebut adalah pembohongan publik yang ditulis dengan kata "ditipu" dan "dikerjain". Dua situasi yang berbeda ditujukan pada respons masyarakat terhadap peristiwa pembohongan publik tersebut. Pada judul juga disebutkan pelaku dari tindakan tersebut yaitu Ria Ricis dan politisi. Melalui judul ini, pembaca dapat mengetahui secara jelas gambaran isi esai yaitu pembahasan mengenai respons masyarakat mengenai isu pembohongan publik. Hal ini diperkuat dengan temuan 
data pada bagian isi esai yang menunjukkan pembahasan mengenai respons masyarakat atas pembohongan publik. Bagian pendahuluan esai ini mendeskripsikan latar belakang penulisan esai yaitu adanya pembicaraan di media sosial yangdisebabkan oleh keputusan Ria Ricis sebagai youtubers atau pembuat konten terkenal di situs youtube yang mengundurkan diri dari akunnya di situs tersebut namun dia mengubah keputusannya sendiri dalam selang waktu yang singkat.

Sudah beberapa hari ini permedsosan meributkan Ria

Ricis. Musababnya apalagi jika bukan soal undur dirinya dari jagad per-youtubean yang mengejutkan penggemarnya. Menjadi semakin berisik lantaran keputusan itu dianulir Ria Ricis sendiri hanya berselang dua hari dari kejadian pertama. Alhasil, beragam nyinyiran muncul dari netizen yang kesal. (Harjatno, 2019)

Penulis kemudian membahas peristiwa tersebut ke dalam bagian penjelas atau isi esai. Terdapat 25 paragraf yang menjelaskan permasalahan tersebut dari sudut pandang penulis. Penulis memaparkan gagasannya dengan menggunakan perbandingan dari peristiwa yang hampir serupa, yakni kebohongan yang dilakukan oleh para politisi atau yang disebut penulis dengan kata "prank". Persoalan yang menjadi fokus utama penulis adalah sikap masyarakat yang berbeda terhadap dua peristiwa yang hampir sama ini.

Bisa-bisanya kalian emosi sama Ria Ricis maupun teman-teman youtubersnya itu, padahal di saat yang sama bisa sedemikian sabar dan nrimo-nya dengan segala macam jenis prank para politisi? (Harjatno, 2019)

Di antara sekian juta para pendukung masing-masing capres itu, entah ada berapa orangnya yang sampai bela-belain sampai putus pertemanan, putus silaturahmi, bahkan sampai ditangkap polisi. (Harjatno, 2019)

Lalu begitu pilpres berakhir, para pendukung akar rumput yang sudah habis-habisan ikut serta dalam pertikaian itu dikejutkan dengan jagoan mereka yang malah rekonsiliasi di MRT. Mesra dan penuh keramahan. Jauh beda dibandingkan pidato-pidato kampanye sebelumnya. (Harjatno, 2019)

Perbandingan dua situasi ini ditutup penulis dengan simpulan yang menyebutkan argumen bahwa Ria Ricis melakukan penipuan kepada masyarakat karena mencontoh politisi. Argumen penulis yang terakhir ini menggunakan kalimat tanya pada awal bagian penutup untuk memberi argumen terakhir pada esai ini. Simpulan ini terdapat pada paragraf 30 , 31, dan 32.

Gimana kalau misalnya, apa yang dilakukan oleh Ria Ricis itu semata-mata merupakan sebuah pengalaman dari keteladanan yang sudah dipertontonkan para bapakbapak dan ibu-ibu di Senayan sana? Yah, semacam learn from the best begitu. (Harjatno, 2019)

Data-data kutipan di atas yang berasal dari bagian pendahuluan, isi, dan penutup esai. Ketiga bagian ini sama-sama membahas mengenai isu pembohongan publik yang dilakukan oleh beberapa publik figur seperti yang disebutkan pada judul esai. Hal ini menunjukkan antara judul dan isi esai memiliki keterkaitan.

\section{Pengorganisasian Bahasa Terkait Kohesi dan Koherensi}

Artikel esai merupakan yang terdiri dari beberapa paragraf dengan gagasan pokok masing-masing untuk memaparkan gagasan atau permasalahan utama di dalam esai. Pengembangan paragraf di dalam esai 
mempunyai dua syarat utama yaitu kohesi atau kesatuan, dan koherensi atau kepaduan. Peranti kohesi dan koherensi paragraf sangat diperlukan untuk memaparkan gagasan penulis secara rinci dan runtut. Peranti kohesi menurut Rohmadi dan Nasucha (2010) terbagi menjadi dua, yaitu kohesi gramatikal dan kohesi leksikal. Kohesi gramatikal meliputi pengacuan personal, pengacuan penunjukan, dan pengacuan pembandingan. Sedangkan peranti kohesi leksikal meliputi repetisi atau pengulangan, antonim, sinonim, dan kolokasi atau sanding kata. Kohesi leksikal juga dapat menunjukkan koherensi di dalam paragraf. Selain peranti kohesi, terdapat pula koherensi yang menunjukkan hubungan antar kalimat di dalam paragraf. Koherensi di dalam paragraf dapat ditunjukkan dengan menggunakan kohesi leksikal dan konjungi atau kata hubung. Berikut adalah contoh pengorganisasian bahasa terkait kohesi dan koherensi di dalam rubrik Esai media online Mojok:

\section{Kohesi gramatikal}

\section{Pengacuan}

Penanda kohesi gramtikal meliputi pengacuan personal, pengacuan penunjukan, dan pengacuan pembanding. Pengacuan personal berfungsi untuk mengetahui tokoh atau pelaku yang terlibat dalam pembahasan masalah. Penngacuan penunjukan dapat menunjukkan tempat terjadinya peristiwa yang tengah dibahas di dalam esai. Lalu pengacuan pembandingan mempunyai fungsi memandingkan suatu objek dengan kata lain yang dapat menggantikannya.

\section{Pengacuan Personal}

Pengacuan personal yang digunakan pada artikel-arikel di dalam rubrik Esai media online Mojok antara lain yaitu kita, kalian, mereka, saya. Anda, ia, dia, kami, kamu, dan you. Pengacuan personal ini terbagi menjadi tiga, yaitu pengacuan personal orang pertama, orang kedua, dan orang ketiga. Pengacuan personal orang pertama yang meliputi kita, saya, dan kami, digunakan penulis esai untuk menunjukkan sudut pandang penulis sebagai orang pertama yang sekaligus menjelaskan bahwa permasalahan yang dibahas di dalam esai berasal dari pengalaman pribadi penulis.

\section{Kita:}

Hal itu seakan mengonfirmasi betapa semakin dangkalnya mutu tontonan masyarakat kita. (Harjatno, 2019)

\section{Saya: \\ Entah dirayakan secara simbolis dengan tiup lilin atau potong tumpeng, saya belum tahu. (Fauzan, 2019) \\ Kami: \\ Kami benar-benar dikejar waktu, karena mengerjakan PR pada malam dalam terang cahaya yang kami sebut lampu pelita bukanlah situasi yang asyik. (Nggarang, 2019)}

Kemudian ada pengacuan orang kedua baik tunggal maupun jamak yang meliputi Anda, kamu, dan you.

Anda:

Anda tertarik mencoba Minyak Kutus Kutus? (Titiesari, 2019)

You:

Youharus rogoh kocek setidaknya Rp. 230.000 untuk mendapatkan 100 mililiter minyak hijau unyu ini. (Titiesari, 2019)

Penggunaan kata Anda dan you di atas merujuk pada pembaca esai. Penulis memberikan argumennya secara langsung kepada membaca dengan menyebut mereka sebagai orang kedua yang terlibat dalam pembahasan di dalam esai secara langsung. Sedangkan kata kamu merujuk kepada pelaku dari permaslahan yang terjadi. Pada data yang ditemukan peneliti, kata kamu digunakan penulis untuk memberikan dua sudut pandang pembahasan yakni dari pelaku terjadinya masalah dan penulis yang mengamati permasalahan tersebut. Seperti yang disebutkan dalam data berikut:

\section{Kamu:}


Bahkan andaikata buku seluruh Kiri di seluruh dunia ini, sudah tuntas kamu razia, lalu apa? (Harjatno, 2019)

Pengacuan personal orang ketiga meliputi kalian, ia, dan dia. Pengacuan personal orang ketiga yang bersifat jamak ini digunakan penulis untuk menyebutkan pembaca esai sebagai pelaku yang terlibat langsung di dalam pembahasan. Berikut kutipan penggunaan pengacuan personal orang ketiga:

\section{Kalian:}

Kalian bilang orang-orang macam Ria Ricis dan para youtubers itu menipu, ... (Harjatno, 2019)

Ia:

Mungkin tidak membantu banyak, tapi musik selalu mencuri ruang sempit di hati kita, ia adalah tempat rehat kala penat dan jeda penting di saat genting. (Fauzan, 2019)

Dia:

Meskipun sejatinya saya yakin dia nggak akan jajan pijet-pijet, ya karena gajinya itu tadi. (Titiesari, 2019)

\section{Pengacuan Penunjukan}

Pengacuan penunjukan digunakan penulis untuk menunjuk lokasi terjadinya permaslaahan yang dibahas di dalam esai. Di dalam penelitian ini ditemukan dua jenis pengacuan penunjukan yaitu ini dan sana. Kedua pengacuan penunjukan ini memiliki fungsi yang berbeda. Ini menunjuk tempat yang dekat dengan penulis esai, sedangkan sana menunjuk tempat yang jauh dari penulis. Berikut data-data kutipan pemakaian pengacuan penunjukan:

Ini:

Bukankah ini pertanda Islam tercabut dari lokalitas yang semula mendukung kehadirannya di belahan bumi ini? (Basuki, 2019)

Sana:

Di sana, air tidak hadir satu per satu ke rumah. (Nggarang, 2019)

Pengacuan Pembanding
Pengacuan pembanding digunakan penulis untuk membandingkan objek permasalahan dengan kata lain. pada penelitian ini, pengacuan pembanding yang ditemukan adalah ini, yang membanding objek yang dekat, itu dan situ yang membandingkan objek yang jauh. Berikut contoh data kutipan pemakaiannya:

Ini

Dikira dukun bayi apa ya saya ini? (Khadafi, 2019)

Itu:

Lalu tibalah di momen 9 bulan yang menyebalkan itu. (Khadafi, 2019)

Situ:

Tapi bukan di situ persoalannya. (Harjatno, 2019)

\section{Penggantian}

Penggantian merupakan penggunaan kata yang memiliki kemiripan makna dengan suatu kata (Saddhono dan Slamet, 2010). Pada esa-esai di media online Mojok, penggantian terjadi antarkalimat dan antarparagraf. Satu kata yang memiliki kemiripan makna digunakan untuk mengganti sebuah kata di kalimat atau paragraf lain. hal ini menunjukkan adanya kesatuan pikiran mengenai permasalahan yang dibahas, baik pelaku maupun objeknya. Berikut dat penggunaan penggantian yang ditemukan peneliti:

Ketika akhirnya lahir, kegelisahan soal nama anak laki-laki benarbenar sempat terlupa. (Khadafi, 2019)

Semua rencana nama anak selama berbulan-bulan hilang. (Khadafi, 2019)

\section{Pelesapan}

Penanda kohesi gramatikal yang terakhir adalah pelesapan. Pelesapan merupakan penghilangan sebagian kata (Rohmadi dan Nasucha, 2010). Pelesapan digunakan untuk menghilang beberapa kalimat yang mengikuti kalimat lain namun masih mempunyai pokok pikiran yang sama. 
Di kampung-kampung pedalaman, persoalannya bisa jauh lebih pelik. Apalagi saat musim hujan. (Nggarang, 2019)

Lalu kamu sambat mereka mau diajak berpikir gimana lagi? Ya, sulit. (Harjatno, 2019)

\section{Kohesi Leksikal}

Penanda kohesi yang kedua adalah penanda kohesi leksikal atau kesatuan makna. Penanda kohesi leksikal digunakan untuk menunjukkan kesatuan makna antar masing-masing kalimat di dalam paragraf. Penanda kohesi leksikal meliputi empat jenis, yaitu repetisi atau pengulangan kata, antonimi atau perlawanan kata, sinonimi atau persamaan kata, dan kolokasi atau sanding kata. Berikut penjabaran dari penggunaan penanda kohesi leksikal pada rubrik Esai media online Mojok.

\section{Repetisi}

Repetisi atau pengulangan kata adalah penanda kohesi leksikal yang berfungsi untuk menunjukkan kesatuan pikiran melalui kata-kata yang bermakna sama di dalam suatu paragraf. Berikut contoh data-data kutipan penggunaan repetisi pada rubrik Esai media online Mojok:

Sudah beberapa hari ini jagad permedsosan meributkan Ria Ricis. (Harjatno, 2019)

Menjadi semakin berisik lantaran keputusan itu dianulir Ria Ricis sendiri ... (Harjatno, 2019)

\section{Antonimi}

Antonimi atau perlawanan kata adalah penggunaan dua kata yang memiliki makna kontras dengan makna kata lain.antonimi menjadi penanda kesatuan pikiran mengenai satu permalasahan dengan dua sudut pandang yang berlawanan. Pada penelitian ini, antonimi ditemukan pada beberapa kalimat yang berada di dalam satu paragraf.

Lomba-lomba masa kecil saya berbeda dengan masa sekarang. (Seno, 2019)
Dulu, lomba-lomba seperti dirancang untuk memancing penonton. (Seno, 2019)

\section{Sinonimi}

Penanda kohesi eksikal selanjutnya adalah sinonimi atau persamaan kata. Kata-kata yang memiliki kemiripan makna digunakan untuk memberikan variasi tanpa merusak kesatuan dan kepaduan paragraf. Berikut contoh penggunaan sinonimi pada sampel esai:

Berapa lama sih karier sebagai atlet bisa bertahan? (K2/P21/E4)

Itu pun kemampuan fisiknya sudah mulai menurun seiring popularitasnya. (Setiawan, 2019)

\section{Kolokasi}

Kolokasi atau sanding kata adalah pemggantian beberapa kata ke dalam sebuah kata atau sebaliknya yang mana kata tersebut dapat saling mewakili makna di dalamnya.

Bagi orang kampung seperti kami, mati listrik adalah persoalan teknis. (Nggarang, 2019)

Mengerjakan PR tidak bisa, masak jadi sulit, episode sinetron jadi terlewat. (Nggarang, 2019)

\section{Penanda Konjungsi}

Konjungsi atau kata hubung meripakan salah satu penanda koherensi. Pada penelitian ini, konjungsi dugnakan untuk menghubungkan dua kata, dua frasa atau dua klausa di dalam sebuah kalimat. Terdapat beberapa fungsi dari penggunaan konjungsi di dalam kalimat seperti hubungan kedudukan setara, hubungan kedudukan berlawanan, sebab akibat, pelaku, dan pengandaian. Hal ini menunjukkan bahwa kalimat-kalimat di dalam paragraf itu koheren.

Pada penelitian ini, ditemukan 17 jenis konjungsi yang dibagi empat berdasarkan fungsinya di dalam kalimat. Konjungsi yang menghubungkan dua kata atau klausa berkedudukan setara adalah dan, atau, serta maupun. Beikut contoh pemakaiannya: 
Saya juga tidak tahu apa motif dan alasan mereka. (Khadafi, 2019)

Antara melangkah maju atau tidak. (Seno, 2019)

Yang kemudian bikin orang lain ragu pada MKK adalah klaim berlebihan dari bakul, baik asli maupun abal-abal, yang bilang bahwa MKK menyembuhkan berbagai hingga segala macam penyakit. (Titiesari, 2019)

Penanda konjungsi selanjutnya adalah tetapi, meski, dan meskipun. Ketiganya menunjukkan perlawanan makna suatu kata di dalam kalimat. Berikut kutipan data penggunaannya:

Iya sih, romantis, tapi bikin mata sakit. (Nggarang, 2019)

Transjakarta sih tetap jalan meski mati listrik. (Nggarang, 2019)

Penanda konjungsi sebab akibat merupakan konjungsi yang paling banyak ditemukan pada penelitian ini. Penulis menggunakan konjungsi yang berfungsi menjelaskan sebab akibat untuk merunutkan kronologi permasalahan dan memudahkan pembaca memahami permasalahan secara urut. Pemaparan permasalah secara kronologi ini juga menunjukkan adanya kepaduan dari tiao paragraf di dalam esai. Penggunaan konjungsi ini menunjukkan bahwa permasalahan yang dibahas di dalam esai memiliki sebab akibat yang menjadi dasar kuat dari setiap argumen yang dipaparkan oleh penulis. Penanda konjungsi sebab akibat mencakup jika, karena, lalu, jadi, menjadi, maka, agar, kalau, kalaupun, walaupun, hingga, sehingga, dan sebab. Berikut contoh data kutipan pemakaian konjungsi sebab akibat:

Jika berpikir jernih saja pun bukanlah opsi, maka apalagi berpikir adil. (Harjatno, 2019)

Hanya karena kelahiran kakak saya terjadi ketika NASA berhasil mendaratkan manusia ke bulan. (Khadafi, 2019)

Situasi ini mirip seperti orang kota yang masuk di desa, lalu menamainya sebagai wisata alam. (Nggarang, 2019)

Hidup dalam gelap sambil ditemani ritme ritmis air hujan sudah jadi kebudayaan. (Nggarang, 2019

Denny menilai kalau orang Jakarta itu cengeng. (Nggarang, 2019)

Telepon hanya dilakukan bila pulsa ada, sehingga tuntutan untuk ngecas hape pun jarang. (Khadafi, 2019)

Saya pernah khawatir dengan hal ini, sebab salah seorang kawan pernah berkata, .. (Titiesari, 2019)

Jenis penanda konjungsi yang terakhir adalah konjungsi yang berfungsi untuk menunjukkan pelaku dalam sebuah kalimat. Konjungsi ini ditunjukkan dengan kata oleh. Berikut data kutipan pemakaian konjungsi pelaku pada penelitian ini:

Bahkan seandainya Ria Ricis dan Atta Halilintar nyapres pun, mereka akan dengan mudah digilas oleh kandidat lainnya kok. (Harjatno, 2019)

\section{Efektivitas Struktur Kalimat}

Kalimat merupakan unsur utama pembentuk esai. Kalimat yang digunakan di dalam esai harus efektif agar argumen penulis dalam pembahasan masalah dapat dengan mudah dipahami pembaca secara tepat sesuai apa yang dimaksud oleh penulis. Dua hal yang menjadi syarat keefektifan kalimat adalah struktur dan ciri-ciri kalimat efektif (Putrayasa, 2012). Jenis kalimat efektif ada tiga, yaitu struktur kalimat umum di mana inti kalimat ditulis terlebih dahulu kemuaduan diikuti unsurunsur tambahan, struktur kalimat paralel yang mencakup kesejajaran bentuk dan makna, serta struktur kalimat periodik di mana unsur pendukung kalimat ditulis terlebih dahulu baru kemudian diikuti inti kalimat. Sedangkan ciri-ciri kalimat efektif yaitu kesatuan, kehematan, penekanan, dan variasi. Berikut beberapa data penggunaan tiga struktur kalimat yang memenuhi ciri- 
ciri kalimat efektif dalam rubrik Esai media online Mojok:

\section{Kalimat Umum}

$\underline{\text { Hal itu seakan mengonfirmasi }}$

$\mathbf{S}$ betapa semakin dangkalnya mutu

K. Sifat

tontonan masyarakat kita.

O

(Harjatno, 2019)

\section{Kalimat Paralel}

Tidak apa kita mengeluarkan 230 ribu untuk anggaran belanja MKK, karena banyak hal yang bisa didapat dan dihemat. (Titiesari, 2019)

Asal pas dan cocok gitu aja. (Khadafi, 2019)

\section{Kalimat Periodik}

Tanggal 17 Agustus mendatang,

K. Waktu

$\underline{\text { FPI akan merayakan ulang tahun }}$

\section{$\mathbf{P}$} O

$\underline{\text { ke-21 }}$

(Fauzan, 2019)

\section{Ketepatan Penggunaan Diksi}

Pembahasan masalah di dalam esai memerlukan diksi yang tepat. Ketepatan penggunaan diksi sangat berpengaruh terhadap keberhasilan penulis menyampaikan pandangannya terhadap permasalahan tersebut sekaligus menarik minat pembaca. Ketepatan penggunaan dikis menurut Gorys Keraf 2007 mencakup kata umum dan kata khusus, kata indria (panca indra), perluasan arti kata, penyempitan arti kata, ameliorasi (peningkatan makna), peyorasi (penurunan makna), metafora, dan metonimi. Berikut penjabaran data-data ketepatan penggunaan diksi pada rubrik Esai media online Mojok:

\section{Kata Umum}

Minyak-minyak ini didapat dengan cara mengekstrak tanaman. (Titiesari, 2019)

\section{Kata Khusus}

Sudah bikin malu, saya malah nggak kebagian makan daging bebek. (Seno, 2019)

\section{Kata Indria}

Lagu ini bisa didengar lewat album Sekilas Info. (Fauzan, 2019)

\section{Perluasan Arti}

Di sisi lain, ada juga yang mencitrakan kubunya sebagai gerbong anti orba. (Harjatno, 2019)

\section{Ameliorasi}

Kenapa tidak minta nama dari istri? (Khadafi, 2019)

\section{Peyorasi}

Kan orangtua jadi bisa numpang hidup dari hasil adsense yang dihasilkan. (Setiawan, 2019)

Metafora

Toh mengharumkan nama bangsa itu sudah tidak zaman lagi. (Setiawan, 2019)

\section{Metonimi}

Anak-anak seumuran saya sudah tahu apa yang harus dilakukan. (Nggarang, 2019)

Ketepatan penggunaan diksi pada sepuluh esai sampel dapat dikatakan telah terpenuhi. Pada masing-masing sampel ditemukan data-data penggunaan jenis kata umum, kata khusus, perluasan arti, penyempitan arti, ameliorasi, peyorasi, metafora, dan metonimi. Penggunaan delapan jenis kata ini sudah secara tepat secara penulisan dan fungsi di dalam kalimat.

\section{Ketepatan Ejaan Dan Tanda Baca}

Ketepatan ejaan dan tanda baca pada penelitian ini dibagia menjadi tiga, yakni ketepatan pemakaian huruf, penulisan kata, penggunaan tanda baca, dan penulisan unsur serapan. Pemakaian huruf meliputi pemakaian huruf diftong, gabungan huruf konsonan, huruf kapital, dan huruf miring. Huruf kapital digunakan pada semua awal kalimat semua sampel esai. Berikut contoh pemakaian huruf diftong, gabungan huruf konsonan, dan huruf miring: 
Semua karya yang memuat judul dan nama yang berbau kiri wajib dirazia. (Nggarang, 2019)

Bahkan muncul peluang koalisi bareng. (Harjatno, 2019)

"I can kill cause in God I trust!" teriak Eddie Vedder menyindir, "It's evolution, Baby!" (Harjatno, 2019)

Penulisan kata meliputi kata dasar, kata berimbuhan, bentuk ulang, kata depan, gabungan kata, singkatan dan akronim, serta angka dan bilangan. Berikut adalah data-data kutipan penulisan kata yang benar dalam sepuluh sampel esai:

Bahkan dianggap mewakili agama segala. (Harjatno, 2019)

Hal itu seakan mengonfirmasi betapa semakin dangkalnya mutu tontonan masyarakat kita. (Harjatno, 2019)

Kira-kira apa coba yang terjadi? (Khadafi, 2019)

Jika melihat nasib mantan atlet bulu tangkis kita akan lebih miris lagi. (Setiawan, 2019)

Wah, saya langsung jadi anak dan menantu salehah di mata mereka. (Titiesari, 2019)

Nah, ketika SD, cara pandang saya berbeda lagi. (Seno, 2019)

Pada pemakaian tanda baca, ditemukan data penggunaan tanda titik, tanda koma, tanda hubung, tanda pisah, tanda tanya, tanda seru, dan tanda petik. Tanda titik digunakan sebagai penanda akhir kalimat pada semua esai. Berikut beberapa contoh data pemakaian tanda baca pada penelitian ini:

\section{Tanda Koma}

Entah dirayakan secara simbolis dengan tiup lilin atau potong tumpeng, saya belum tahu pasti. (Fauzan, 2019)

\section{Tanda Hubung}

Tidak boleh serta-merta dipercaya. (Basuki, 2019)

\section{Tanda Pisah}

Pemberontakan terasa sangat personal pada beberapa bagian- terutama di judul lagunya.

(Fauzan, 2019)

Tanda Tanya

Ada yang kayak gitu? (Harjatno, 2019)

\section{Tanda Seru}

Hati ini ingin berteriak:

"Kembalikan jam tidurku!"

\section{Tanda Petik}

"Halah, baru calon atlet bulu tangkis, belum tentu jadi atlet juga." (Setiawan, 2019)

Penggunaan ejaan dan tanda baca pada rubrik Esai media online Mojok sudah tepat. Meskipun masih ditemui beberapa kesalahan pada esai tertentu, sebagian besar penggunaan ejaan dan tanda baca pada sampel penelitian sudah tepat. Penggunaan ejaan yang meliputi penulisan huruf dan kata telah sesuai dengan Pedoman Umum Ejaan Bahasa Indonesia (PUEBI). Penulisan tanda baca juga sudah tepat sesuai pedoman tersebut.

\section{Relevansi Penggunaan Bahasa Indonesia Pada Rubrik Esai Mojok Dengan Pembelajaran Menulis Artikel Di Sekolah Menengah Atas}

Berdasarkan hasil penelitian ini, dapat diketahui bahwa penggunaan bahasa Indonesia pada rubrik Esai media online Mojok mempunyai relevansi dengan pembelajaran menulis artikel di sekolah menengah asatas. Berdasarkah hasil penelitian mengenai keterkaitan judul dengan isi, pengorganisasian kohesi dan koherensi, keefektifan kalimat, penggunaan diksi, serta penggunaan ejaan dan tanda baca dapat direlevansikan dengan pembelajaran menulis artikel di sekolah menengah atas. Pembelajaran menulis artikel harus sesuai dengan kurikulum yang berlaku saat ini, yaitu kurikulum 2013 edisi revisi 2016. Pembelajaran menulis artikel sangat penting bagi siswa karena dapat diimplementasikan dalam kehidupan sehari-hari siswa dan dapat menambah daya kreasi siswa. 
Pernyataan tersebut selaras dengan hasil penelitian mengenai pengembangan paragraf di dalam esai yang dilakukan oleh Budiyono (2012). Paragraf sebuah esai memiliki ciri-ciri khusus yang mencakup proses pembuatan kalimat tesis, pembinaan relevansi isi terhadap topik penerapan retorika dalam tulisan, serta penerapan kebahsaan paragraf. Retorika sebuah tulisan mencakup fungsi, posisi, kelengkapan unsusr, kohesi, koherensi serta keruntutan paragraf. Sedangkan kebahasaan sebuah tulisan dapat diterapkan melalui penyusunan kalimatkalimat efektif, penggunaan diksi, dan penggunaan ejaan dan tanda baca.

\section{SIMPULAN}

Hasil penelitian dan pembahasan penggunaan bahasa Indonesia pada rubrik Esai media online Mojok dapat disimpulkan sebagai berikut. Pertama, Esai-esai yang terdapat pada rubrik Esai media online Mojok menunjukkan keterkaitan antara judul dengan isi yang didukung dengan pemaparan masalah pada bagian pendahuluan, isi, dan penutup esai sesuai dengan masalah yang disebutkan pada judul.

Kedua, pengorganisasian bahasa Indonesia rubrik Esai media online Mojok dibagi menjadi dua aspek, yaitu kohesi yang meliputi kohesi gramatikal dan leksikal serta koherensi yang ditandai dengan penggunaan konjungsi. Kohesi gramatikal meliputi pegacuan personal, pengacuan penunjukan, dan pengacuan pembanding, penggantian dan pelesapan. Penanda kohesi leksikal meliputi repetisi, antonimi, sinonimi, dan kolokasi. Pengorganisasian aspek kohesi dan

\section{REFERENSI}

Basuki, N. (2019). Larangan Logo Halal di Cina dan Budaya Gagal Paham Indonesia.

https://mojok.co/nvb/esai/larangan -logo-halal-di-cina-dan-budayagagal-paham-indonesia/ koherensi di dalam paragraf telah terstruktur dengan baik. Sedangkan pengorganisasian kohesi dan koherensi antar paragraf kurang terbangun karena terdapat beberapa paragraf yang tidak memenuhi syarat sebagai paragraf.

Ketiga, efektivitas kalimat rubrik Esai media online Mojok dianalisis berdasarkan jenis struktur kalimat yang mencakup tiga jenis, yaitu kalimat umum, kalimat paralel, dan kalimat periodik dan ciri-cirinya yang meliputi kesatuan, kehematan, penekanan, dan variasi. Rubrik Esai media online Mojok telah memenuhi syarat sebagai kalimat efektif karena telah memuat ketiga jenis struktur kalimat yang memiliki ciri-ciri kalimat efektif.

Keempat, rubrik esai media online Mojok sudah menggunakan diksi pada setiap esainya secara tepat. Penggunaan diksi pada rubrik Esai media online Mojok terbagi dalam delapan jenis diksi berdasarkan ketepatan penggunaannya yang meliputi jenis kata umum, kata khusus, perluasan arti, penyempitan arti, ameliorasi, peyorasi, metafora, dan metonimi.

Kelima, penggunaan ejaan dan tanda baca pada rubrik Esai media online Mojok terbagi menjadi tiga yaitu pemakaian huruf yang meliputi pemakaian huruf diftong, gabungan huruf konsonan, huruf kapital, dan huruf miring, penulisan kata yang meliputi kata dasar, kata berimbuhan, bentuk ulang, gabungan kata, kata depan, sinonim dan akronim, serta pemakaian tanda baca yang meliputi pemakaian tanda titik, tanda koma, tanda hubung, tanda pisah, tanda tanya, tanda seru, dan tanda petik.

Dalman (2015). Penulisan Populer. Jakarta: Rajawali Press.

Fauzan, M. N. (2019). Jelang ulang tahun FPI dan Mixtape Perpanjangan Izin Ormas. https://mojok.co/mfu/esai/jelang- 
ulang-tahun-fpi-dan-mixtapeperpanjangan-izin-ormas/

Harjatno, I. (2019). Kesel Ditipu Ria Ricis tapi Kok Tahan Dikerjain Politisi. https://mojok.co/isj/esai/keselditipu-ria-ricis-tapi-kok-tahandikerjain-politisi/

Harjatno, I. (2019). Razia Buku Kiri itu Candu.

https://mojok.co/isj/esai/raziabuku-kiri-adalah-candu/

Helaludin. (2017). Analisis Struktur Esai Mahasiswa pada Mata Kuliah Bahasa Indonesia di IAIN Sultan Maulana Hasanuddin Banten. Bindo Sastra, 1 (1), 15-20.

Khadafi, A. (2019). Kasih Nama Anak Laki-laki Ternyata Memang Butuh Negosiasi. https://mojok.co/daf/esai/kasihnama-anak-laki-laki-ternyatamemang-butuh-negosiasi/

Khadafi, A. (2019). Jika Google Mendadak Hilang dari Dunia Ini Gara-gara Digugat Donald Trump. https://mojok.co/daf/esai/jikagoogle-mendadak-hilang-daridunia-ini-karena-digugat-donaldtrump/

Nggarang, Y. B. F. (2019). Uniknya Homo Jakartanicus, Menderita karena Mati Listrik tapi Tetap Pingin Eksis. https://mojok.co/ybfn/esai/uniknya -homo-jakartanicus-menderitakarena-mati-listrik-tapi-tetappingin-eksis/

Numertayasa, I. W., Sutarna, I.M., dan Rasna. (2013). Analisis Wacana Esai Kajian Struktur Supra, Struktur Mikro dan Makro pada Esai Hasil Pelatihan Menulis Esai Sekolah Menengah Pertama SeKecamatan Rendang Tahun 2011. e-Journal Program Pascasarjana Universitas Pendidikan Ganesha, 2 (4).

Putrayasa, I. B. (2012). Kalimat Efektif. Bandung: Refika Aditama.

Seno, Y. (2019). 17 Agustus dalam Ingatan Anak SD. https://mojok.co/yms/esai/17agustus-dalam-ingatan-anak-sd/

Setiawan. (2019). Terima Kasih KPAI, Sudah Selamatkan Anak-anak dari Mimpi menjadi Atlet Dunia. https://mojok.co/sa/esai/terimakasih-kpai-sudah-selamatkananak-anak-dari-mimpi-menjadiatlet-dunia/

Titiesari, Y. D. (2019). Habis Tupperware, terbitlah Minyak Kutus Kutus. https://mojok.co/ydt/esai/habistupperware-terbitlah-minyakkutus-kutus/ 